\title{
Rancang Bangun Perangkat Keras Penunjuk Menggunakan Lengan Atas Dengan Konektivitas Bluetooth
}

\author{
${ }^{1}$ Yusuf Giovanno, ${ }^{2}$ Romy Budhi Widodo, ${ }^{3}$ Oesman Hendra Kelana \\ 1,2,3 Pusat Studi Human Machine Interaction Teknik Informatika, Universitas Ma Chung, J1. Villa Puncak \\ Tidar N-01, Malang, Indonesia, 65151
}

Correspondence: Yusuf Giovanno (yusufgiovanno91@ gmail.com) Received: 150821 - Revised: 160821 - Accepted: 010921 - Published: 261021

\begin{abstract}
Abstrak. Perangkat penunjuk memberikan bantuan dalam pengoperasian komputer. Perancangan perangkat mouse menggunakan lengan atas bertujuan untuk membantu penyandang tunadaksa untuk mengoperasikan komputer dengan lebih baik. Prototipe mouse perlu dilengkapi dengan fasilitas klik untuk menggantikan tombol klik mouse. Penelitian ini bertujuan untuk meneliti mana yang lebih baik penggunaan tombol klik di kaki kiri (prototipe A) atau kaki kanan (prototipe B). Sedangkan penggerak kursor sendiri menggunakan sensor di lengan atas. Penelitian dilakukan dengan menggunakan metode penilaian Fitts' Law yang diterapkan oleh ISO 9241-411, pengujian dilakukan dengan 9 subjek non tunadaksa. Subjek melakukan pengujian dengan menggunakan perangkat lunak untuk melakukan pengujian multi-directional tapping sesuai standar ISO 9241-411. Pengisian kuesioner untuk memperoleh data kualitatif dilakukan setelah pengujian menggunakan perangkat lunak. Penyaringan data dilakukan untuk menghilangkan galat, dan ketika data telah siap, dilakukan pengujian statistik untuk menguji performa, tingkat kenyamanan, dan tingkat kelelahan. Pengujian performa dilakukan menggunakan data Time of Movement dan Throughput, sedangkan untuk pengujian tingkat kenyamanan menggunakan Assessment of Comfort, dan untuk pengujian tingkat kelelahan menggunakan Assessment of Fatigue. Berdasarkan pengujian statistik dapat dinyatakan bahwa mouse memiliki performa lebih baik dari kedua prototipe yang ada, hal ini dibuktikan dengan unggulnya mouse terhadap nilai Throughput dengan perbedaan nilai 3,96 (bit/s) untuk prototipe A dan 3,86 (bit/s) untuk prototipe B serta rendahnya nilai Time of Movement dengan perbedaan 7,83 detik untuk prototipe A dan 6,58 detik untuk prototipe B. Perbedaan nilai Time of Movement dan Throughput antara kedua prototipe tidaklah signifikan, hal ini menandakan bahwa penggunaan kaki kanan / kiri tidak terlalu berpengaruh terrhadap performa prototipe. Secara umum prototipe dapat digunakan untuk menggantikan mouse, namun peningkatan performa terkait Throughput dan Time of Movement akan membuat prototipe lebih layak untuk digunakan.
\end{abstract}

Kata kunci: disabilitas, tunadaksa, mouse, sensor inersial, mikrokontroller

Citation Format: Giovanno Y., Widodo, R.B. \& Kelana, O.H.. (2021). Rancang Bangun Perangkat Keras Penunjuk Menggunakan Lengan Atas Dengan Konektivitas Bluetooth. Prosiding Seminar Nasional Sistem Informasi dan Informatika Ma Chung, 2021, 81-90. 


\section{PENDAHULUAN}

Perkembangan zaman saat ini membuat komputer menjadi sebuah perangkat yang wajib dimiliki untuk mempermudah aktivitas, baik aktivitas sehari-hari suatu individu maupun aktivitas penunjang pekerjaan suatu korporasi. Dalam pengoperasian komputer diperlukan alat masukan berupa penunjuk (pointer) dan papan tik (keyboard). Alat penunjuk telah mengalami berbagai perubahan yang membuat pengoperasian komputer menjadi lebih mudah bagi pengguna tanpa kebutuhan khusus, namun bentuk dan pengoperasian alat penunjuk masa kini pada umumnya tidak cocok untuk pengguna dengan kebutuhan khusus terutama untuk penyandang tunadaksa.

Alat penunjuk komputer yang ada di pasar pada umumnya memiliki bentuk yang serupa. Alat penunjuk saat ini dikembangkan untuk tiga golongan yakni golongan umum, pemain video game, dan orang-orang yang bergerak di bidang desain grafis. Dengan demikian alat penunjuk masa kini didesain dengan desain ergonomis untuk kenyamanan genggam dan pengoperasian pengguna tanpa kebutuhan khusus, hal ini membuat penyandang disabilitas khususunya tunadaksa mengalami kesulitan dalam menggunakannya.

Survei Angkatan Kerja Nasional yang dilakukan oleh Badan Pusat Statistik dengan 131.339 responden dengan usia responden di atas 15 tahun menjelaskan bahwa terdapat $12,15 \%$ responden yang menyandang disabilitas secara umum. Berdasarkan pemetaan yang dilakukan oleh Lembaga Penyelidikan Ekonomi dan Masyarakat Fakultas Ekonomi dan Bisnis Universitas Indonesia menunjukkan bahwa hanya 2,42\% penyandang disabilitas berat yang memiliki pekerjaan formal, dan 3,5\% penyandang disabilitas ringan yang memiliki pekerjaan formal (Badan Pusat Statistik RI, 2016). Dari data yang telah tersaji di atas, dapat diketahui bahwa angka pengangguran pada penyandang disabilitas sangatlah tinggi. Hal ini mendasari penulis untuk melakukan penelitian ini.

Sebelumnya telah terdapat sebuah penelitian yang menggunakan sensor inersial untuk menjadi alat penunjuk. Penelitian terdahulu, perangkat yang dibuat dapat bekerja dengan baik sebagai penggerak pointer, namun terdapat kekurangan yaitu dalam penerapan fungsi klik kiri yang menggunakan flex sensor yang cukup melelahkan untuk digunakan, selain itu konektivitas bluetooth yang digunakan menggunakan modul Bluetooth HC-05 yang harus dipasang pada Arduino UNO sehingga jika terdapat goncangan yang dapat mengakibatkan kabel terlepas atau longgar maka perangkat akan berhenti bekerja (Widodo et al., 2019, 2020a, 2020b). 
Penilaian efektifitas dan efisiensi perangkat ini menggunakan standar internasional dari International Organization for Standardization (ISO). Standar ISO yang digunakan ialah ISO 9241-411 (ISO, 2012). berdasarkan pemaparan latar belakang di atas, diharapkan penelitian ini dapat menjawab pokok permasalahan yang ada.

\section{METODE PELAKSANAAN}

\section{Analisis Kebutuhan}

Penyandang tuna daksa masih memiliki potensi gerak pada lengan bagian atas. Pergerakan yang dapat dilakukan ialah pergerakan pada sendi peluru yang mewakili 3 sudut yakni yaw, pitch, dan roll. Pergerakan yang dapat dilakukan memungkinkan pengguna untuk dapat mengoperasikan perangkat prototipe untuk menggerakkan penunjuk pada layar monitor. Dengan memanfaatkan kaki, pengguna dapat mengaktifkan sebuah saklar yang akan aktif ketika diinjak, saklar ini dikenal dengan nama footswitch (Peterson, 2005).

\section{Prototipe Perangkat}

Terdapat dua blok dalam prototipe yang dibuat. Yang pertama adalah blok pengendali mikro yang terdiri dari footswitch, sensor inersial, dan pengendali mikro untuk blok kedua merupakan sebuah komputer dengan sistem operasi Microsoft Windows 10. Kedua blok terhubung melalui sambungan nirkabel bluetooth. Diagram blok prototipe perangkat dapat dilihat pada gambar 1. Pemasangan perangkat dapat dilihat pada gambar 2 .

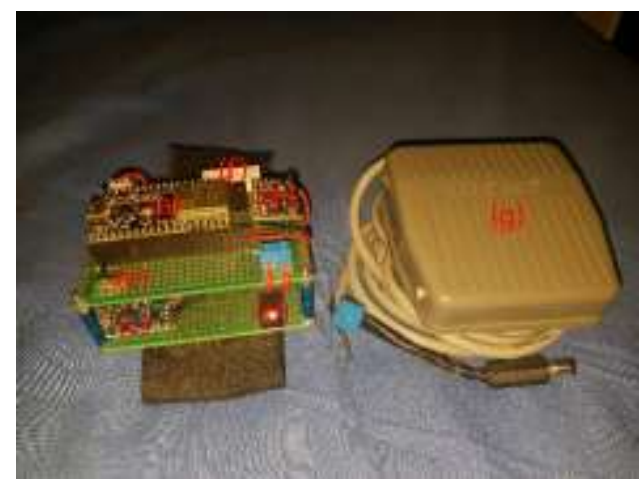

Gambar 1. Prototipe perangkat.

Gambar 1 memuat bentuk fisik prototipe yang terdiri dari ESP32 Devkit-C (a), Sensor GY951 (b). modul charger (c), socket DC (d), saklar (e), voltmeter (f), dan footswitch (g). 


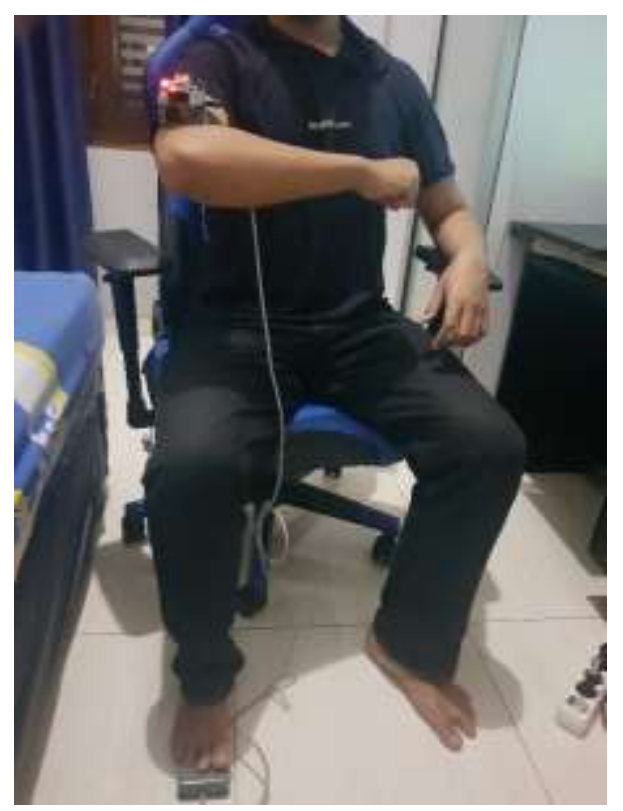

Gambar 2. Pemasangan prototipe pada lengan atas dan footswitch di kaki kanan untuk fungsi klik.

\section{Translasi Data}

Data yang diterima oleh komputer berupa nilai sensor (pitch, roll) dan kondisi footswitch (HIGH atau LOW) akan ditranslasi menjadi pergerakan kursor dan fungsi klik dengan bantuan perangkat lunak yang dibuat menggunakan Bahasa Pemrograman Python. Data berupa String akan diterima dan dipecah menjadi lima bagian yakni yaw, pitch, roll, klik kiri, dan klik kanan. Pergerakan penunjuk akan dimulai pada titik tengah layar, selanjutnya data yaw, pitch, roll akan digunakan sebagai acuan untuk melakukan pergerakan atau perpindahan penunjuk pada posisi selanjutnya (kiri, kanan, atas, bawah). Untuk menentukan fungsi klik, data klik kiri dan klik kanan yang berupa angka 0 dan 1 akan dijadikan acuan dengan angka 1 sebagai sebuah perintah untuk melakukan sebuah fungsi klik.

Gambar 3 menunjukkan ilustrasi translasi data sensor inersial dan footswitch menjadi pergerakan kursor. Ilustrasi monitor komputer yang memiliki empat titik yakni $\mathrm{X}+, \mathrm{X}-, \mathrm{Y}+$, dan $\mathrm{Y}-$. kursor akan bergerak sesuai pergerakan lengan pengguna. Ketika pengguna melakukan gerakan flexion maka kursor akan bergerak pada sumbu $\mathrm{Y}+$ atau ke arah atas, jika pengguna melakukan ekstension maka kursor akan bergerak terhadap sumbu Y- atau ke bawah, jika pengguna melakukan gerakan outward maka kursor akan bergerak ke sumbu X-atau ke arah kiri, dan jika pengguna melakukan gerakan inward maka kursor akan bergerak ke sumbu $\mathrm{X}+$ atau arah kanan. 

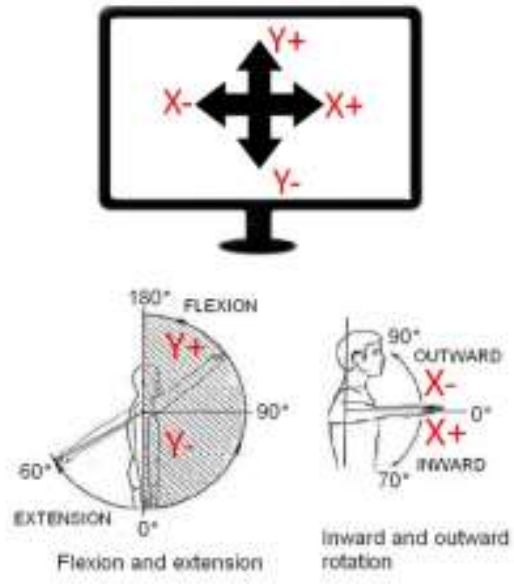

Gambar 3. Ilustrasi pergerakan kursor.

\section{Pengujian Data}

Pengujian data dilakukan dengan menggunakan dua metode yakni parametrik dan non parametrik. Uji parametrik diterapkan pada data kuantitatif dan uji non parametrik diterapkan pada data kualitatif. Alur uji data statistik dimuat pada gambar 4.

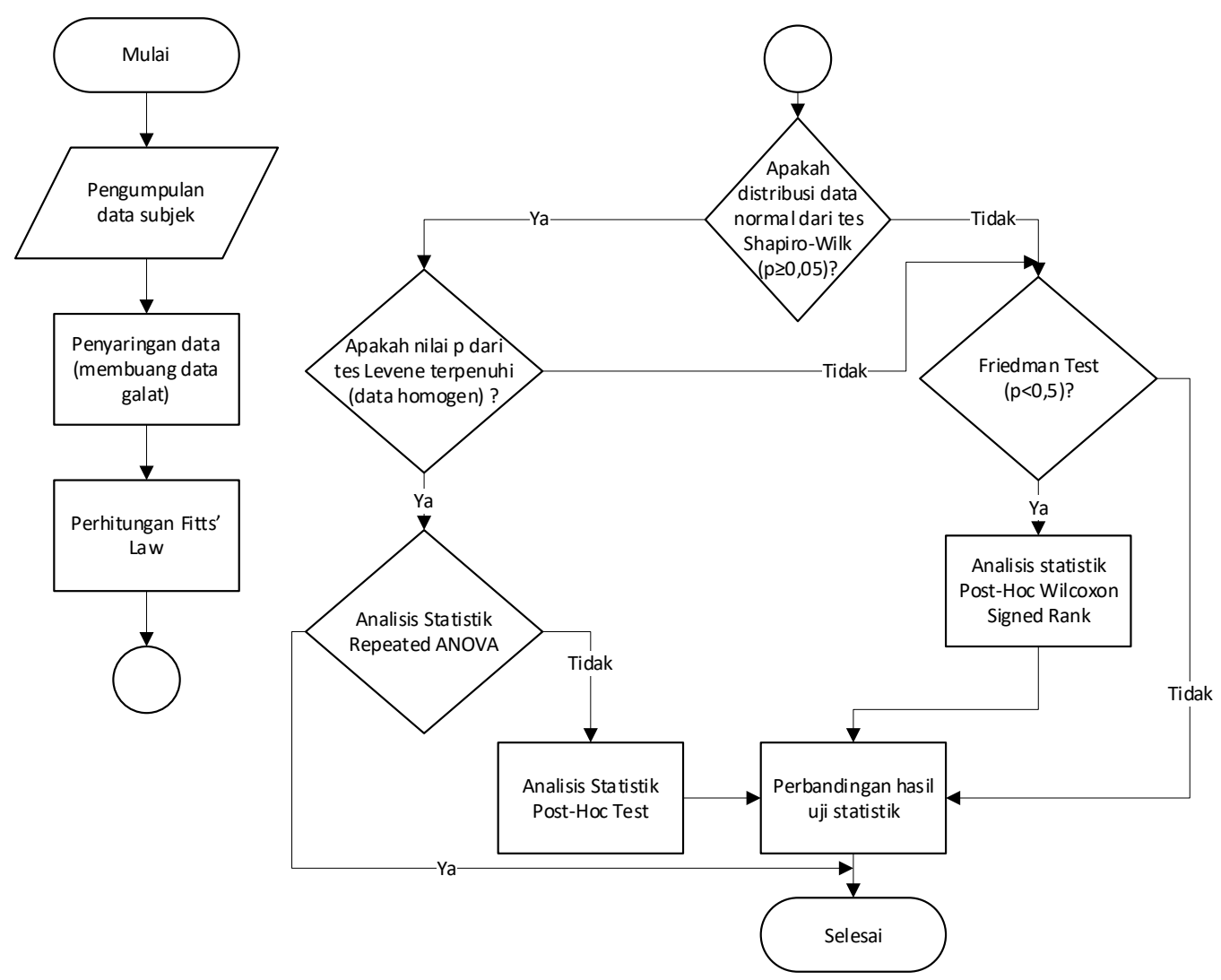

Gambar 4. Alur uji statistik. 
Pengujian data melibatkan metode uji Shapiro-Wilk, Levene, Repeated ANOVA, Post-Hoc, Friedman, Wilcoxon Signed Rank, dan Spearman Test. Pengujian Spearman ditambahkan untuk menguji apakah terdapat korelasi antara Prototipe A (footswitch di kaki kanan) dan Prototipe B (footswitch di kaki kiri) dalam tingkat kenyamanan dan kelelahan.

\section{HASIL DAN PEMBAHASAN}

\section{Alat dan Komponen}

Penelitian ini menghasilkan dua perangkat, yakni perangkat lunak dan perangkat keras (prototipe). Perangkat keras berguna untuk mengambil data dari footswitch dan sensor untuk dikirim ke komputer. Perangkat lunak berfungsi untuk menerima dan melakukan translasi data menjadi gerakan kursor dan fungsi klik. Bentuk fisik prototipe dan tampilan antarmuka perangkat lunak dimuat pada gambar 5.

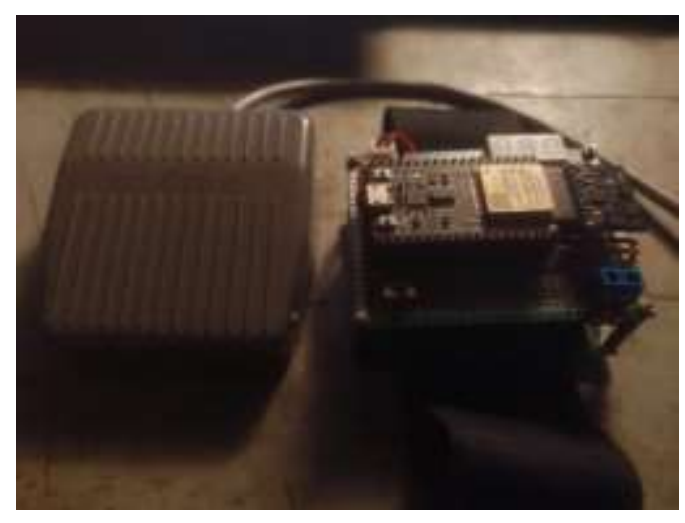

a

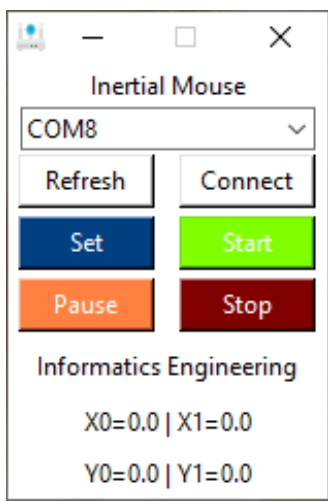

$\mathrm{b}$

Gambar 5. Bentuk fisik prototipe (a) dan antarmuka perangkat lunak (b).

\section{Pengambilan Data}

Pengambilan data dilakukan secara berkala dengan mengatur pertemuan dengan responden terlebih dahulu. Pengambilan data dilakukan di beberapa tempat seperti Universitas Ma Chung, tempat tinggal peneliti, dan tempat tinggal responden. Dalam masing-masing pertemuan, dilakukan pengambilan data sebanyak tiga kali yakni menggunakan mouse, prototipe A dan prototipe B. Demografi subjek dimuat pada tabel 1. 
Tabel 1. Demografi Sebaran Responden

\begin{tabular}{cccc}
\hline Subjek & Jenis Kelamin & Usia & Profesi \\
\hline P1 & L & 23 & Mahasiswa \\
P2 & L & 23 & Mahasiswa \\
P3 & P & 23 & Mahasiswa \\
P4 & L & 23 & Mahasiswa \\
P5 & L & 20 & Wiraswasta \\
P6 & L & 25 & Wiraswasta \\
P7 & L & 23 & Mahasiswa \\
P8 & L & 23 & Mahasiswa \\
P9 & L & 25 & Mahasiswa \\
\hline
\end{tabular}

\section{Penyajian Data}

Data uji prototipe menggunakan aplikasi GoFitts yang memuat data mengenai Time of Movement dan Throughput. Perhitungan Time of Movement dan Throughput diperoleh dari Fitts' Law (Mackenzie, 2018). disajikan dalam bentuk tabel yang dimuat pada tabel 2 berikut.

Tabel 2. Tabel Penyajian Data Kuantitatif Aplikasi GoFitts Untuk Masing-masing Perangkat

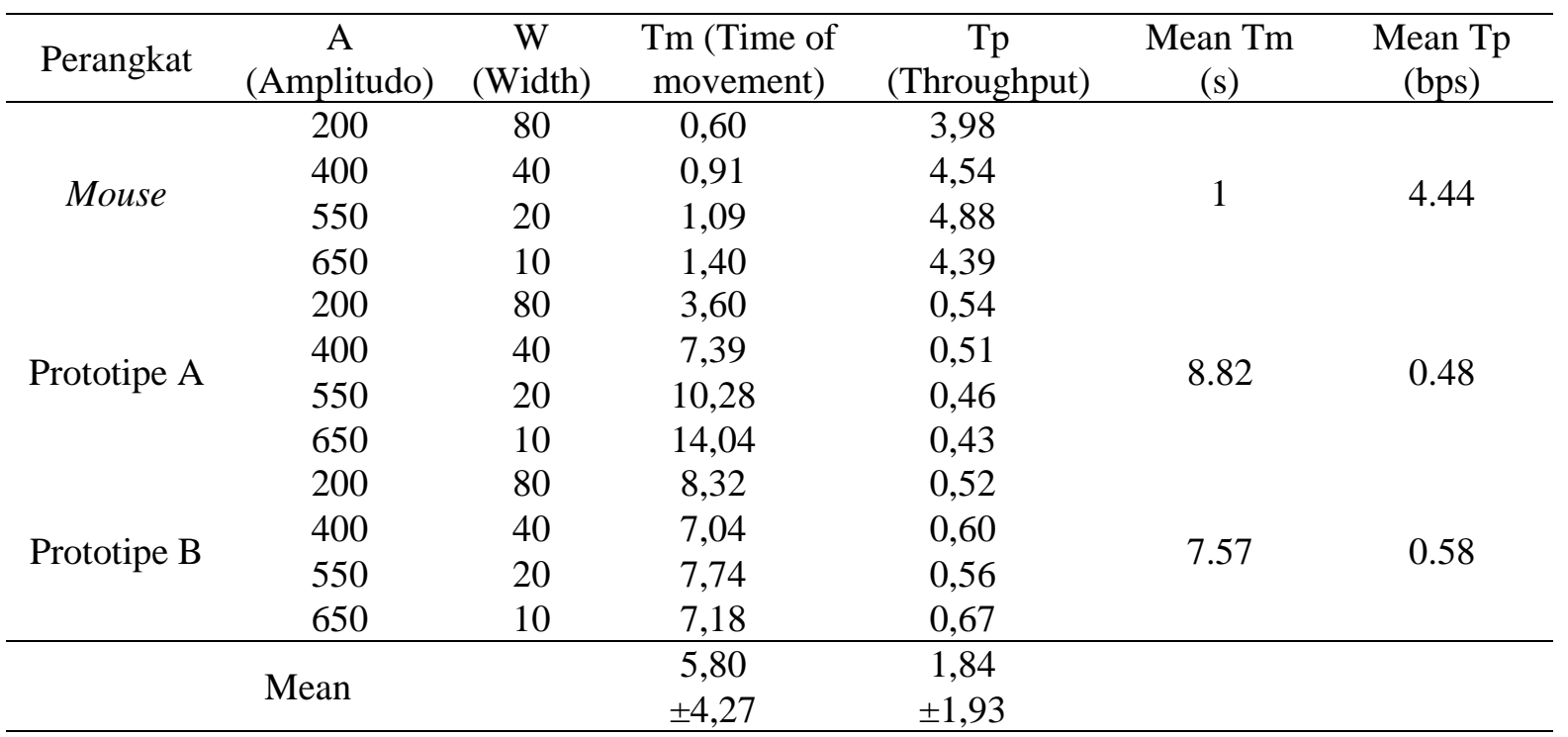

\section{Hasil Analisis Data Kuantitatif}


Penyebaran data direpresentasikan ke dalam bentuk boxplot. Representasi data Time of Movement dan data Throughput dimuat pada gambar 6 dengan sumbu y sebagai besaran nilai dalam pengambilan data uji.

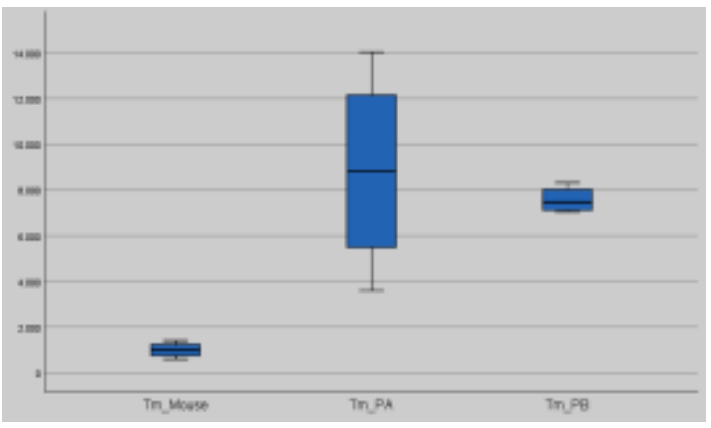

a

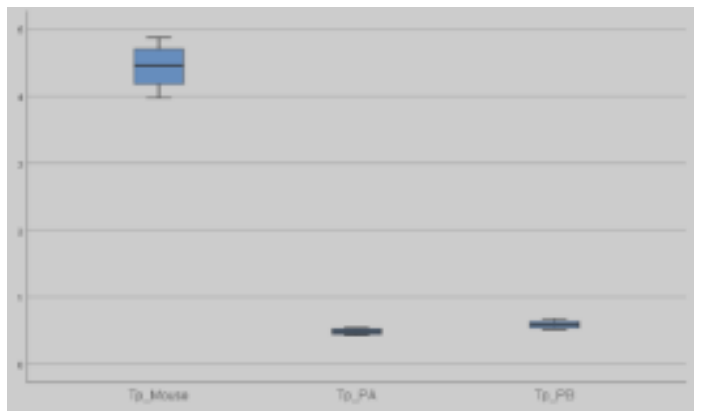

b

Gambar 6. Boxplot data Time of Movement (a) dan Boxplot data Throughput (b).

Pengujian kuantitatif memberikan hasil seperti berikut:

1. Perangkat mouse memiliki nilai mean yang berbeda secara signifikan dibandingkan dengan kedua prototipe berdasarkan uji Wilcoxon Signed Rank.

2. Perangkat mouse memiliki performa lebih baik karena nilai $\mathrm{Tm}$ dan $\mathrm{Tp}$ yang jauh lebih baik dari kedua perangkat lain.

3. Prototipe A dan Prototipe B tidak memiliki perbedaan yang signifikan.

\section{Hasil Analisis Data Kualitatif}

Hasil uji Wilcoxon Signed Rank menunjukkan bahwa perangkat mouse memiliki tingkat kenyamanan lebih baik dengan nilai sebanyak 49 data pada masing-masing perangkat. Untuk Prototipe A dan Prototipe B tidak memiliki perbedaan tingkat kenyamanan yang signifikan dengan 47 data yang memiliki nilai sama.

Hasil uji Wilcoxon Signed Rank menunjukkan bahwa perangkat mouse memiliki tingkat kelelahan lebih kecil dengan nilai sebanyak \pm 28 data pada masing-masing perangkat. Untuk Prototipe A dan Prototipe B tidak memiliki perbedaan tingkat kenyamanan yang signifikan dengan 38 data yang memiliki nilai sama.

Hasil uji Spearman menunjukkan bahwa Prototipe A dan Prototipe B memiliki korelasi yang kuat yang menandakan bahwa tingkat kelelahan dan kenyamanan kedua perangkat ini tidak memiliki perbedaan yang signifikan.

\section{Diskusi}


Penelitian ini dilakukan dengan subjek yang bukan penyandang tuna daksa. Data yang dikumpulkan akan lebih baik hasilnya jika data diambil menggunakan subjek penyandang tuna daksa dengan jumlah sebanyak mungkin. Beberapa subjek telah mencoba perangkat serupa sebelumnya sehingga diasumsikan memiliki tingkat kemahiran yang lebih dibandingkan dengan subjek yang belum pernah menggunakan perangkat serupa.

Meninjau dari penelitian sebelumnya yang membuat perangkat serupa menggunakan metode klik yang berbeda. Pada penelitian ini pendeteksian klik dilakukan menggunakan dua buah sensor yang diuji secara bergantian. Dua buah sensor ini masing-masing dipasang di pundak dan di otot yang membuatnya melelahkan untuk dilakukan. Perangkat yang dirancang penulis menggunakan sebuah footswitch dengan metode flag dengan tingkat kesalahan klik yang minimum.

\section{KESIMPULAN}

Pengembangan lanjut akan membuat perangkat ini lebih baik untuk digunakan. Penambahan beberapa fitur seperti konektivitas nirkabel untuk footswitch ke pengendali mikro, penambahan klik kanan, dan perbaikan algoritma penerjemahan data akan memberikan dampak yang signifikan. Penyesuaian ukuran strap agar dapat digunakan oleh pengguna dengan ukuran lingkar lengan yang berbeda-beda dan pengurangan dimensi alat akan membuat alat lebih nyaman untuk digunakan.

\section{UCAPAN TERIMA KASIH}

Ucapan terima kasih atas dukungan dan bantuan yang diberikan untuk penelitian ini disampaikan kepada:

1. Tuhan Yang Maha Esa atas berkat dan rahmat yang diberikan hingga terselesaikannya penelitian ini.

2. Kedua orang tua serta keluarga yang senantiasa memberi dukungan dalam segala hal yang tidak dapat tergantikan.

3. Bapak Dr.Eng Romy Budhi Widodo, Bapak Ir. Oesman Hendra Kelana M.Div, M.Cs, dan Bapak Hendry Setiawan., ST., M.Kom. selaku pembimbing, penguji, dan tenaga pendidik yang telah menyalurkan ilmu nya selama perkuliahan.

4. Bapak Paulus Lucky Tirma Irawan, S.Kom., MT., Bapak Mochamad Subianto, S.Kom., M.Cs., Bapak Windra Swastika, Ph.D., Ibu Dr. Kestrilia Rega Prilianti, M.Si, Ibu Reyna Marsya Quita, S.Si, M.Sc., Ibu Melissa Hans Wianto, Bapak Ritchie Sudarmaji, S.Mn., M.Ec., Bapak Rudy Setiawan., S.Si., M.T., dan Bapak Vincentius Valiandy Jiuangga, S.Kom., MTCSOL yang telah menyalurkan ilmu nya selama perkuliahan. 
5. Gede Putu Adityawarman Okadhana, Ernanda Kusuma Wardhana, Rendy Jhon Kailola, Daffa Oldy Saputra, Adam Lazuardi Haris, Daniel Adiwiranata Santoso, Devina Trixie, Robby Juniansyah dan segenap rekan-rekan yang telah memberi dukungan selama menempuh pendidikan di Universitas Ma Chung.

\section{DAFTAR PUSTAKA}

Badan Pusat Statistik RI, 2016. Katalog Data Mikro: Survei Angkatan Kerja Nasional, Jakarta: Badan Pusat Statistik RI.

ISO, 2012. Evaluation Methods for The Design of Physical Input Device. s.1.:ISO.

Mackenzie, S., 2018. Handbook of human-computer interaction, pp. 349-370.

Peterson, R. H. et al, 2005. Footswitch, United States Patent.

Widodo, R. B. et al, 2019. The IMU and Bend Sensor as a Pointing Device and Click Method. International Seminar on Intelligent Technology and Its Applications (ISITIA), pp. 306-309

Widodo, R. B. et al, 2020a. Design and Evaluation of Upper-Arm Mouse using Inertial Sensor for Human-Computer Interaction., Journal of Engineering Science and Technology, Vol.15, No.6, pp. 3673-3690

Widodo, R. B. et al, 2020b. The Combination of Foot Switch and Low-Cost IMU for a Wearable Mouse in Human-computer Interaction.

(C) 2021 by authors. Content on this article is licensed under a Creative Commons Attribution 4.0 International license. (http://creativecommons.org/licenses/by/4.0/). 